Copyright (@ 2009 Institute of Electrical and electronics Engineers, Inc.

All Rights reserved.

Personal use of this material, including one hard copy reproduction, is permitted.

Permission to reprint, republish and/or distribute this material in whole or in part for any other purposes must be obtained from the IEEE.

For information on obtaining permission, send an e-mail message to stds-igr@ieee.org.

By choosing to view this document, you agree to all provisions of the copyright laws protecting it.

Individual documents posted on this site may carry slightly different copyright restrictions.

For specific document information, check the copyright notice at the beginning of each document. 


\title{
Integrated Model for Sustainable Development
}

\author{
Vineet. H. Varma' and Gopi Chattopadhyay ${ }^{2}$ \\ Central Queensland University, Faculty of Science, Engineering and Health \\ PELM, Gladstone Campus \\ Bryan Jordan Drive, Gladstone, QLD, 4680, AUSTRALIA \\ v.varma@cqu.edu.au and g.chattopadhyay@cqu.edu.au
}

\begin{abstract}
The growing human population has put an everincreasing strain on world resources. This is causing a severe imbalance on human lives and the flora and fauna of the world. Human activities in areas such as mining, deforestation, urban development and industrialization have created an adverse impact on environmental, social and economic stability of companies and countries. This paper will take an integrated and holistic approach to address these problems and focus on deriving the maximum value from a bundle of available resource to enhance sustainability. It would consider 'ValueStream analysis, to improve the efficiency and effectiveness of the business. This paper is aimed to address the financial, economic, social and environmental aspects at a macro level for achieving sustainability and enhance quality of life.
\end{abstract}

Keyword - Sustainable Development, Value Stream

\section{INTRODUCTION}

"We're living in an era where technologies have empowered high living standards and longer life expectancies," [1]. The growing human population has been causing an ever-increasing strain on world resources. Human activities in areas such as mining, deforestation, urban development and industrialization have created adverse impact on environmental, social and economic stability of companies and countries. An integrated and holistic approach is required to address these problems. This would help in deriving maximum value from a bundle of available resource to enhance sustainability. It is proposed to adapt value stream approach to improve efficiency and effectiveness of businesses. Figure 1 explains interrelation of elements in sustainable development.

This paper has analyzed existing sustainability models and proposed an integrated model to address the financial, economic, social and environmental aspects at a macro level for achieving sustainability and enhance quality of life.

\section{OVERVIEW OF SUSTAINABLE DEVELOPMENT}

The Brundtland Commission coined the definition of sustainable development as "Development that meets the needs of the present generation without compromising the ability of future generations to meet their own needs". Since the Brundtland Report of 1987, Sustainable development (SD) has become an important topic on the world's policy agenda. Governments have committed themselves to sustainable development by integrating economic welfare, environmental quality and social coherence [2]. Reference [3] proposed two key ideas: i) well-being of future generations and ii) bi-directional impacts from economic activities on the state of the environment and natural resources.

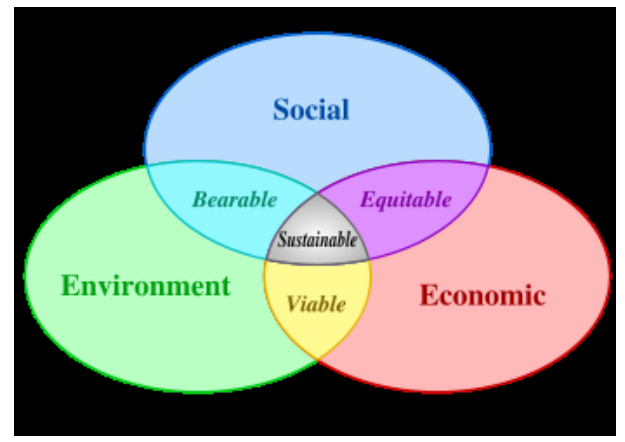

Figure 1: Elements of Sustainable Development [4]

\section{A. Hierarchies of sustainable development}

There is a limited capacity of the planet to meet the increasing demand for resources and to absorb the emissions and waste resulting from their use. There is evidence that the existing demand exceeds the carrying capacity of the environment in several cases [5]. People who describe the interaction between economic, social and environmental dimension of sustainability advocate that society depends on the economy. But an economy without society is impossible [6]. Economic capital is 'man made' from natural resources or by increase of the market value such as increase in share 
value or value of paintings. Social and natural capitals therefore are preconditions for economic capital [7]. The economic capital does not put any priority for social and happiness aspect. For the social capital to exist and flourish it needs to take the aid of environmental capital. Hence the environmental capital emerges as a precondition for the existence and durability of social capital. Even though these preconditions are met and efforts are put together for sustenance, systems often do not perform to their potential. Could there be a precondition for these elements to exist. There are unanswered questions on quality of life and the general happiness of a community in decision making influencing sustainability of a system.

\section{B. Sustainability indicators}

Monitoring progress towards SD requires identification of operational indicators that provide manageable units of information on economic, environmental, and social conditions. The Compendium of Sustainable Development Indicator initiatives consider more than 500 sustainable indicators [8]. However, no single measure does a perfect job at reflecting sustainable development and policies [3].

\section{Evaluation of the indicators}

Figure 2 underlines the fact that there are shortcomings in the current indicators followed by various researchers and organizations. Some of these are as follows [9]-[17]:

- SD indices are far from reflecting the holistic nature of sustainability. Environmental impact takes precedence over the other elements of sustainability.

- Data availability limits modeling and validation of user-friendly indicators.

- Models can be country specific as sustainability requirements may be viewed differently across countries [18].

- Normalization and weighting, do not have universally accepted rules. From a policy-making perspective insignificant variables could be assigned high values due to politically sensitive issues and therefore, novel challenges to SD might not be considered in an objective manner [2].

\section{Comparing organizations on relevant dimensions of sustainability}

Sustainability is emerging as a new trend in corporate reporting, integrating financial, environmental, and social aspects of performance of the company. To date, more than 3000 corporate environmental, social or sustainability reports have been published on a voluntary basis [19]. A message that comes out of these reports is that everyone is benefited when companies take better care of human and natural resources.

\begin{tabular}{|c|c|c|c|c|}
\hline Source & Metrics & $\begin{array}{c}\text { Environmental } \\
\text { Impact }\end{array}$ & Social Impact & $\begin{array}{l}\text { Economic } \\
\text { Impact }\end{array}$ \\
\hline \begin{tabular}{|l} 
Myriam Nourry, \\
2008.Universite de \\
Nantes
\end{tabular} & $\begin{array}{l}\text { Green national } \\
\text { net product }\end{array}$ & 1 & 1 & 5 \\
\hline \begin{tabular}{|l} 
Myriam Nourry, \\
2008.Universite de \\
Nantes
\end{tabular} & Genuine Savings & 3 & 3 & 5 \\
\hline \begin{tabular}{|l|} 
Myriam Nourry, \\
2008.Universite de \\
Nantes
\end{tabular} & \begin{tabular}{c|} 
Genuine Progress \\
Indicator (GPI)
\end{tabular} & 5 & 4 & 5 \\
\hline \begin{tabular}{|l|}
$\begin{array}{l}\text { Mathis Wackernagel } \\
\text { and Rees (1996), UN }\end{array}$ \\
\end{tabular} & $\begin{array}{l}\text { Ecological } \\
\text { footprint }\end{array}$ & 5 & 1 & 3 \\
\hline ISO14040 (2006) & $\begin{array}{l}\text { Life Cycle } \\
\text { Assessment }\end{array}$ & 5 & 1 & 3 \\
\hline $\begin{array}{l}\text { Figge et al (2006), } \\
\text { Institute of Strategic } \\
\text { Research, Buhhapest }\end{array}$ & $\begin{array}{c}\text { Sustainable } \\
\text { Value Approach }\end{array}$ & 3 & 2 & 4 \\
\hline \begin{tabular}{|} 
Yale Center for \\
Environmental Law \\
\& Policy (2006, \\
2008), World \\
Economic Forum
\end{tabular} & $\begin{array}{l}\text { Environmental } \\
\text { Sustainability } \\
\text { Index }\end{array}$ & 5 & 1 & 1 \\
\hline \begin{tabular}{|c|} 
Daly (1996), World \\
Bank
\end{tabular} & The "Daly Rules" & 5 & 1 & 2 \\
\hline \begin{tabular}{c|}
$\begin{array}{c}\text { Bohringer and } \\
\text { Jochem (2007) }\end{array}$ \\
\end{tabular} & \begin{tabular}{|c|} 
The well-bentg \\
index (WI)
\end{tabular} & 3 & 5 & 1 \\
\hline $\begin{array}{l}\text { Bohringer and } \\
\text { Jochem (2007) }\end{array}$ & $\begin{array}{l}\text { Enviromentent } \\
\text { Sustainability } \\
\text { Index (ESI) }\end{array}$ & 5 & 1 & 1 \\
\hline SOPAC(2005) & $\begin{array}{l}\text { Environment } \\
\text { Vulnerability } \\
\text { Index (EVI) }\end{array}$ & 5 & 1 & 1 \\
\hline $\begin{array}{l}\text { Bohringer and } \\
\text { Jochem (2007) }\end{array}$ & $\begin{array}{l}\text { Environmenta } \\
\text { Performance } \\
\text { Index (EPI) }\end{array}$ & 5 & 1 & 1 \\
\hline \begin{tabular}{|c|} 
International Finance \\
Corporation (IFC),
\end{tabular} & $\begin{array}{c}\text { Equator } \\
\text { Principles (EPs) }\end{array}$ & 3 & 3 & 3 \\
\hline WWF (1998) & $\begin{array}{l}\text { Living P Panet } \\
\text { Index (LPI) }\end{array}$ & 5 & 1 & 1 \\
\hline UNCHS (2001) & $\begin{array}{l}\text { Development } \\
\text { Index (CDI) }\end{array}$ & 3 & 3 & 3 \\
\hline
\end{tabular}

Figure 2: Efficacy of SD indicators (5- indicates strong relation)

The Equator Principles (EPs) originally adopted by banks, led by Citigroup, ABN AMRO, Barclays is a voluntary set of guidelines for assessing environmental and social risks in financing projects. According to Sharon Maharg, the Regional Head of Sustainability Management at WestLB - "Major financial institutions are committed to financing only environmentally and socially responsible projects." [20].

\section{PROPOSED MODEL}

There are basically three different target groups for sustainability assessment: scientists, decision makers and individuals [21]. Scientists are interested primarily in statistically useable and segregated data, while decision makers require aggregated data, as well as relating data to goals and criteria. Individual users (the public) prefer aggregation of data to one meaningful, easy to understand value (i.e. an index). The current practice does not consider an essential outcome, the quality of life, into consideration. It also does not separate financial outcomes from economic outcomes. Moreover most of the models look at an industry, local, regional or a national framework and do not consider the value stream of products and services for sustainable development. This paper addresses these shortcomings and 
proposes a more comprehensive model covering financial, economic, social, environmental and quality of life and looks from a holistic perspectives - using value stream analysis for a more transparent and objective model useful for decision making by stake holders.

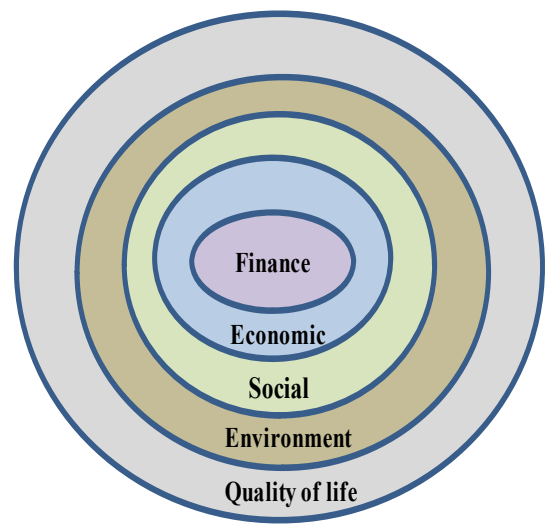

Figure 3: Proposed framework for Sustainable Development

\section{A. Quality of life and Sustainability}

According to Philip Sutton (Director, Policy and Strategy, Green Innovations Inc) there are two levels of sustainability:

1. Maintenance of basic sustainability and usefully referred to as 'survival sustainability' and

2. Maintenance/ restoration of the normally expected quality of life.

Measures put together for 'survival sustainability' would need to consider the quality of life of people being affected. Quality of life is extremely complex to define. Neo-classical economist claim that high consumption of goods equates to higher levels of happiness. But general happiness of a population transcends beyond economic growth. The Well-Being Index (WI) by Prescott [22] which measures the health of the environment to gauge the health of healthy humans and the Genuine Progress Indicator (GPI) which attempts to correct the GDP by integrating not only ecological but also social and political variables are some of the indicators proposed to link sustainability with quality of life at a macro level [23]. Global National Happiness (GNH) a term coined by Bhutan's King Jigme Singye Wangchuck in 1972, states that there are measures other than economic growth that defines the general well being of a population. Med Yones, President of International Institute of Management in 2006 stated that along with economic growth the other important factors for general happiness are Environmental, Physical, Mental, Workplace, Social and Political wellness. The model proposed in this paper tries to depict the hierarchies between the elements of sustainability development and introduces additional elements to explain the need for an integrated and holistic model.

\section{B. Life cycle issues}

Analyses on SD often correspond to the activities that create value within individual organizations. Environmental or social impacts that are caused by suppliers or customers are not taken into account. A great majority of management attention has historically gone to managing aggregates processes, departments, firms - overseeing many products at once. Yet what's really needed is to manage whole value streams for specific goods and services and estimate the overall impact on sustainable development using value stream analysis of the whole life cycle of a product/ service. During the last three decades, the focus on optimizing operations has moved from a specific facility or organization to the entire value streams. By optimizing along the entire sequence of steps that are involved in the production of a product or providing service, the greatest the value can be realized at the lowest possible cost. A focus on value streams is a step towards the broader adoption and development of sustainability starting from initial processing to final use by the customer [24]. Sustainable product and/or service development (SPSD) is defined as the process of making products and/ or services in a more sustainable way throughout their entire lifecycle, from conception to end of life. This is interpreted as being to achieve an optimum balance between environmental protection, social equity and economic prosperity while meeting traditional product requirements, e.g. quality, market, technical and cost issues. The goal of SPSD is to produce products and/or to provide services, which are sustainable and achieve their required functionality, meet customer requirements and are cost effective [25].

\section{The Value Stream}

Value Stream Mapping is a 'Lean technique' used to analyze the flow of materials and information currently required to bring a product or service to a consumer. At Toyota, where the technique originated, it is known as "Material and Information Flow Mapping" [26]. Figure 4 depicts the steps of 'coal' from extraction to its use. 


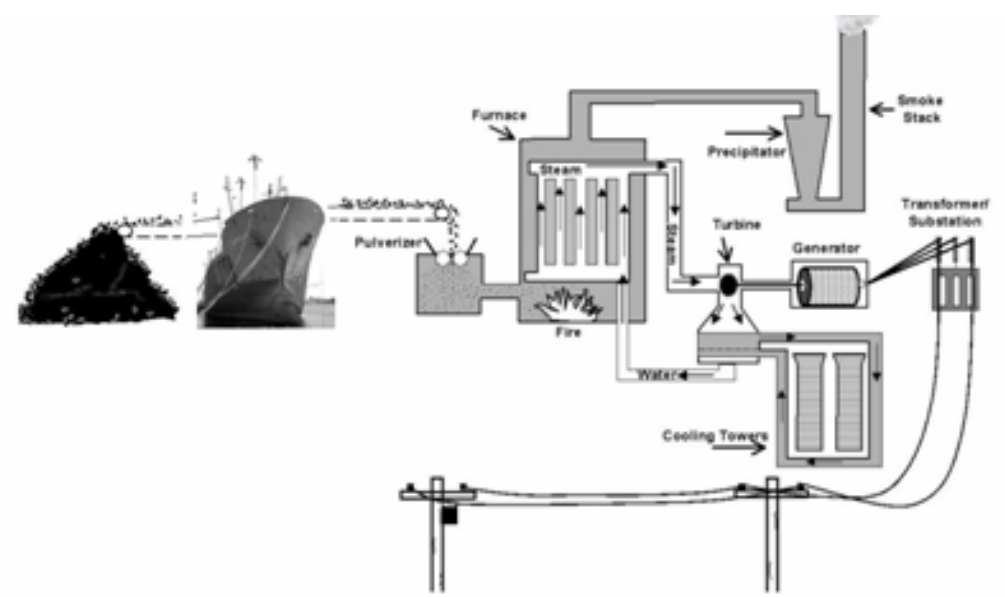

Figure 4: Power generation in a coal fired plant in India/China [27]

D. How sustainable is the business if countries/ regions alter their activities

For any industry to be sustainable it is necessary to look at the whole value stream and address all elements of SD as proposed in this paper. System boundaries are not defined well in 'existing SD models'. Interdependency between players in the value stream is completely ignored, and the time to achieve SD is unclear. The existing models look at SD from an operational perspective rather than addressing the strategic challenges.

\section{E. 'Space-time-value stream' Model}

A 'Space-time-value stream' model is proposed where $\mathrm{T}$ axis shows short - medium - long term time windows in Figure 5. $\mathrm{X}$ axis shows the space (country, region and global organizations in the value stream). Y axis shows pillars of sustainable development (Financial, Economic, social, environmental and quality of life) and $\mathrm{Z}$ axis shows themes (Health, education, economic development, bio-diversity, atmosphere, land, poverty, governance, fresh water, ocean seas and coasts, demographics, natural hazards, global economic partnership and consumption and production patterns). Indicators will help to measure performance against these themes to support the pillars using 'what if' scenario for various policy decisions. This model would be used as a strategic decision tool by stakeholders to predict the impact on sustainable development. Examples of some of the indicators are given below:

$G D P=C+I+G+(X-M)$

Where, $C=$ consumption, $I=$ gross investment

$G=$ government spending,$X=$ exports, $M=$ imports

$N P V=C t /(1+r) \wedge t$

Where, $t$ - The time of the cash flow, $r$ - the discount rate $\mathrm{Ct}$ - the net cash flow at time $\mathrm{t}$
Co2 emission $=\mathrm{Co} 2(\mathrm{~kg}) /$ Units produced (tonnes) $\mathrm{CH} 4$ emission $=\mathrm{CH} 4(\mathrm{~kg}) /$ Units produced (tonnes) Waste Generated $=(\mathrm{kg}) /$ Units produced (tonnes) VOC emission $=(\mathrm{kg}) /$ Units produced (tonnes)

Unemployment rate $=($ Unemployed workers $/$ Total work force) * 100

Literacy rate $=($ the number of literates aged 15 years and over / the total population in that age range) * 100 Infant Mortality rate $=$ (number of deaths of infants [one year or younger]/ 1000 live births)

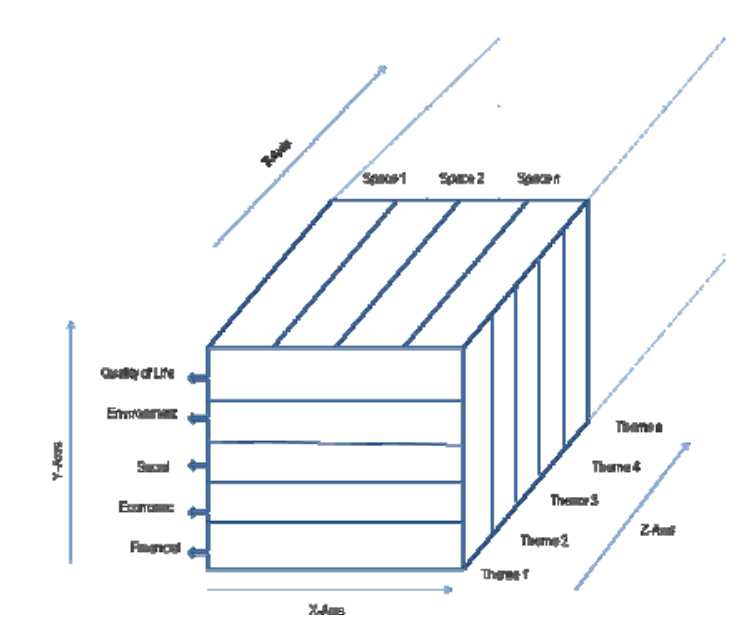

Figure 5: Schematic ‘Space-time-value stream’ model

\section{IV.CONCLUSIONS}

The growing world population has been causing a severe imbalance on human lives along with the flora and fauna of the world. Human activities in areas such as mining, deforestation, urban development and 
industrialization have created adverse impact on environmental, social and economic stability of companies and countries. This paper has proposed 'space-time-value stream' model to enhance sustainable development. The current practices in sustainability measures do not consider an essential outcome, the quality of life, into consideration. It also does not separate financial outcomes from economic outcome. Existing models look at industry, local, regional or at a national level and do not consider the value stream of products and services at a global level. This paper has addressed those shortcomings and proposed a more comprehensive model. The model would be used a strategic tool by stakeholders to take decisions for investments and envisage impacts of potential policy changes and take corrective and preventive actions to mitigate risks of unsustainable developments. Authors are currently working on a full scale model with "what if" scenario analysis using simulation and Analytical Hierarchical Process (AHP) for the coal industry and results would be published in the future.

\section{REFERENCES}

[1] J. Lahart, Nearing the brink, 2008 - The Australian.

[2] C. Böhringer, P.E.P Jochem, Measuring the immeasurable A survey of sustainability indices, Ecological Economics, 2007, Volume 63, Issue 1, 15.

[3] M. Nourry, Measuring sustainable development: Some empirical evidence for France from eight alternative indicators, Ecological Economics, Available online, February 2008.

[4] Answers. com, $3^{\text {rd }}$ August 2008 www.answers.com/topic/sustainable-development

[5] European Union, Decision No. 1600/2002/EC of the European Parliament and of the Council of 22 July 2002 laying down the Sixth Community Environment Action Program , 2002.

[6] J. Elkington, Cannibals with forks, Capstone, Oxford, UK.410 pp, 1999.

[7] V. Mauerhofer, 3-D Sustainability: An approach for priority setting in situation of conflicting interests towards a Sustainable Development, Ecological Economics, Volume 64, Issue 3, 15, 2007.

[8] T. M. Parris, R. W. Kates, Characterizing and Measuring Sustainable Development, Annual Review in Environment and Resource, 2003.
[9] Australian Government - Department of the Environment, Water, Heritage and the Arts http://www.environment.gov.au/settlements/industry/corporat e/lca.html.

[10] D. Krajnc, P. Glavic, How to compare companies on relevant dimensions of sustainability, Ecological Economics, Volume 55, Issue 4,1, 2005.

[11] M. Wackernagel, W.Rees, "Our Ecological Footprint" (New Society Press), 1996.

[12] Yale Center for Environmental Law \& Policy / Center for International Earth Science Information Network at Columbia University, Pilot 2006 Environmental Performance Index, Retrieved on 2007-06-17.

[13] Yale Center for Environmental Law \& Policy / Center for International Earth Science Information Network at Columbia University, Switzerland Tops 2008 Environmental Scorecard at World Economic Forum, Retrieved on 2008-01-26.

[14] H. Daly, Beyond Growth: The Economics of Sustainable Development, Boston: Beacon Press, 1996.

[15] WWF (World Wildlife Fund), Living Planet Report 1998.

[16] UNCHS (United Nations Centre for Human Settlements), The State of the Worlds Cities 2001, UN, Nairobi, 2001.

[17] SOPAC (South Pacific Applied Geoscience Commission), Building resilience in SIDS, The Environmental Vulnerability Index (EVI) 2005, SOPAC Technical Report (Suva, Fiji Islands), 2005.

[18] F. Booysen, An overview and evaluation of composite indices of development, Social Indicators Research 59, 115-151, 2002.

[19] Incorporating an abridged version of the GRI, Sustainability Reporting Guidelines, GRI Mining and Metals Sector Supplement, 2002.

[20] Global View, NDTV, (28/4/2008) http://www.commodityonline.com/ndtv/news/globalviewdetai ls.php?id=7702

[21] L. Braat, The Predictive Meaning of Sustainability Indicators, 1991.

[22] P. Allen, The Wellbeing of Nations: A Country-By-Country Index Of Quality Of Life And The Environment By Robert Published by Island Press, 2001.

[23] Cobb, Clifford, T. Halstead, J. Rowe, The Genuine Progress Indicator: Summary of Data and Methodology, San Francisco, CA: Redefining Progress, 1995.

[24] J.D Linton, R. Klassen, J. Vaidyanathan, Sustainable supply chains: An introduction, Journal of Operations Management, 2007.

[25] D. Maxwell, R. van der Vorst., Developing sustainable products and services, Journal of Cleaner Production 11 (2003).

[26] M. Rother, J. Shook, Learning to see: value-stream mapping to create value and eliminate muda, The Lean Enterprise Institute, Ver. 1.3, 2003.

[27] Kentucky Geological Survey, $3^{\text {rd }}$ Aug, 2008. http://www.uky.edu/KGS/ 